\title{
ACUTE TOXICITY AND CHOLINESTERASE INHIBITION IN CHICKS DOSED ORALLY WITH ORGANOPHOSPHATE INSECTICIDES
}

\author{
Fouad K. MOHAMMAD, Yasser M. AL-BADRANY, and Mohammed M. AL-JOBORY \\ Department of Physiology, Biochemistry and Pharmacology, College of Veterinary Medicine, \\ University of Mosul, Mosul, Iraq
}

Received in March 2008

Accepted in June 2008

\begin{abstract}
Acute toxic effects of three commonly used insecticidal preparations of the organophosphates chlorpyrifos, diazinon, and dichlorvos were examined in mixed breed broiler chicks, and cholinesterase activity in plasma and brain were measured. The acute $(24 \mathrm{~h})$ oral median lethal doses $\left(\mathrm{LD}_{50}\right)$ of chlorpyrifos, diazinon, and dichlorvos were $10.79 \mathrm{mg} \mathrm{kg}^{-1}, 6.32 \mathrm{mg} \mathrm{kg}^{-1}$, and $6.30 \mathrm{mg} \mathrm{kg}^{-1}$, respectively, as determined by the up-and-down method in chicks. Signs of cholinergic toxicosis in the chicks appeared within two hours after dosing, and they included salivation, lacrimation, gasping, frequent defecation, drooping of wings, tremors, convulsions, and recumbency before death. Halving the oral $\mathrm{LD}_{50}$ of chlorpyrifos $\left(5 \mathrm{mg} \mathrm{kg}^{-1}\right)$, diazinon $\left(3 \mathrm{mg} \mathrm{kg}^{-1}\right)$, and dichlorvos $\left(3 \mathrm{mg} \mathrm{kg}^{-1}\right)$ caused immobility and wing drooping, but not the clinical signs of cholinergic toxicity. However, at full $\mathrm{LD}_{50}$ doses of these insecticides, chicks showed clinical signs of cholinergic toxicity similar to those seen in the $\mathrm{LD}_{50}$ experiments. Two out of six chicks died within two hours after treatment with $\mathrm{LD}_{50}$ doses of chlorpyrifos and dichlorvos, whereas $\mathrm{LD}_{50}$ dosing with diazinon caused death in three out of six chicks. Compared to control values, the insecticides reduced plasma and whole brain cholinesterase activities by $29 \%$ to $84 \%$ and $18 \%$ to $77 \%$, respectively, depending on the dose. The decrease in plasma cholinesterase correlated well $(r=0.82)$ with that of the brain. These data suggest that organophosphate insecticides administered orally at $\mathrm{LD}_{50}$ doses induce clinical signs of cholinergic poisoning and concurrently reduce brain and plasma cholinesterase activities in chicks.
\end{abstract}

KEY WORDS: anticholinesterases, chlorpyrifos, cholinergic toxicity, diazinon, dichlorvos, $L D_{50}$

Organophosphate (OP) insecticides are widely used in public health, veterinary practice and agriculture $(1,2)$. They are common in the Middle East, including Iraq. Their main mechanism of toxic action in mammals and birds is to inhibit the target enzyme cholinesterase (ChE), which leads to accumulation of acetylcholine at the nerve terminals and neuromuscular junctions, and to cholinergic overstimulation manifested as muscarinic, nicotinic, and central nervous system effects (3-5). The most important diagnostic or biomarker endpoint of OP exposure and poisoning is decreased $\mathrm{ChE}$ activity in the blood (erythrocytes, plasma or serum) and other tissues, brain in particular (3-8). Birds have no ChE activity in erythrocytes; therefore, the extent of their exposure to and/or OP poisoning is based on $\mathrm{ChE}$ activity in plasma and nervous tissue (3, 9-11).

The toxicity of OP insecticides in birds is generally associated with lower plasma or brain $\mathrm{ChE}$ activities (9, 12-14). Decreases in ChE activity to $50 \%$ or less of the normal is accepted as confirmation of exposure or diagnosis of acute poisoning with these insecticides $(3,15,16)$. Various reports indicate close association between reduced blood or brain $\mathrm{ChE}$ activity and acute 
toxicosis induced by doses close to or higher than the median lethal doses $\left(\mathrm{LD}_{50}\right)$ of OP insecticides in rodents and birds $(3,9,16-19)$.

Chicks have already been used in experimental models of acute or subchronic OP poisoning (1721). Assessing $\mathrm{ChE}$ inhibition profiles in OP poisoned chickens is a widely accepted standard for monitoring toxicosis and lethality $(17,22-24)$. The aim of this study was to further examine the acute toxicity of three commonly used preparations of OP insecticides chlorpyrifos [O,O-diethyl-O-(3,5,6-trichloro-2-pyridyl)phosphorothioate], diazinon [O,O-diethyl-O-(2isopropyl-6-methylpyrimidin-4-yl)phosphorothioate] and dichlorvos (2,2-dichlorovinyl dimethyl phosphate) in chicks. Chlorpyrifos and diazinon inhibit $\mathrm{ChE}$ activity via their active metabolites (25-27), whereas dichlorvos directly inhibits the enzyme (25). Another aim of this study was to see if there is a correlation between plasma and brain cholinesterase activity in chicks dosed with OP insecticides. This will further enhance our understanding of the clinical response of chicks acutely poisoned with OP insecticides, as this animal species is frequently used in the evaluation of acute OP toxicity $(17-24,28,29)$.

\section{MATERIALS AND METHODS}

\section{Animals}

Mixed breed broiler chicks of either sex (7 to 15 days old) were used in the study. They were kept in batches of 20 to 30 chicks at a time in a room at a temperature of $30^{\circ} \mathrm{C}$ to $34^{\circ} \mathrm{C}$ with constant lighting. Floor litter consisted of wood shavings; water and feed were given ad libitum.

\section{Organophosphate insecticides}

We used commercial preparations of three OP insecticides which are common in veterinary practice and public health $(1,2)$. The commercial insecticidal solutions of chlorpyrifos (50\%, Acichlore, VAPCO, Amman, Jordan), diazinon (60\% Diazinon-60EC, VAPCO), and dichlorvos (55\%, SAFA DDVP55EC, Kalite Yonetim, Turkey) were further diluted in distilled water to obtain the desired concentrations for oral dosing by a gavage needle (29) in a volume of $5 \mathrm{~mL} \mathrm{~kg}^{-1}$ body weight. The solutions were freshly prepared before use, and all doses of the OP insecticides were based on the active ingredients of the compounds.

Table 1 24-hour median lethal dose $\left(L D_{50}\right)$ of organophosphate insecticides determined for chicks using the up-and-down method

\begin{tabular}{lc}
\hline Variable & Result \\
\hline Chlorpyrifos & \\
LD $_{50}$ & $10.79 \mathrm{mg} \mathrm{kg}^{-1}$, orally \\
Initial dose & $20 \mathrm{mg} \mathrm{kg}^{-1}$, orally \\
Last dose & $10 \mathrm{mg} \mathrm{kg}^{-1}$, orally \\
Number of chicks used & $5\left(\mathrm{XOXXX}^{*}\right.$ \\
Increase or decrease in dose & $5 \mathrm{mg} \mathrm{kg}^{-1}$, orally \\
Diazinon & \\
LD & \\
Initial dose & $6.32 \mathrm{mg} \mathrm{kg}^{-1}$, orally \\
Last dose & $15 \mathrm{mg} \mathrm{kg}^{-1}$, orally \\
Number of chicks used & $10 \mathrm{mg} \mathrm{kg}^{-1}$, orally \\
Increase or decrease in dose & $6\left(\mathrm{XXXXX}^{*}\right.$ \\
Dichlorvos & $5 \mathrm{mg} \mathrm{kg}^{-1}$, orally \\
LD & \\
Initial dose & $6.30 \mathrm{mg} \mathrm{kg}^{-1}$, orally \\
Last dose & $15 \mathrm{mg} \mathrm{kg}^{-1}$, orally \\
Number of chicks used & $10 \mathrm{mg} \mathrm{kg}^{-1}$, orally \\
Increase or decrease in dose & $6\left(\mathrm{XXOXX}^{*}\right.$ \\
\hline
\end{tabular}

$* X=$ death $; O=$ survival. 


\section{Determination of $L D_{50}$ of $O P$ insecticides}

The acute ( $24 \mathrm{~h}) \mathrm{LD}_{50}$ of each OP insecticide was determined in chicks using the up-and-down method (30). The chicks were individually observed for the appearance of clinical signs of cholinergic toxicosis for two hours after OP dosing, and the 24-hour lethality was recorded.

\section{Acute toxicity of OP insecticides}

After determining the $\mathrm{LD}_{50}$ for each OP insecticide in the previous experiment, we randomised other chicks into three control and six OP groups of six birds each. Control chicks received distilled water at $5 \mathrm{~mL} \mathrm{~kg}^{-1}$ by gavage needle. OP groups received either half or full $\mathrm{LD}_{50}$ single oral doses (corrected to the nearest $\mathrm{mg} \mathrm{kg}^{-1}$ ) of the insecticides: chlorpyrifos at $5 \mathrm{mg} \mathrm{kg}^{-1}$ (half the $\mathrm{LD}_{50}$ dose) or $11 \mathrm{mg} \mathrm{kg}^{-1}$ (full $\mathrm{LD}_{50}$ dose) and diazinon and dichlorvos at $3 \mathrm{mg} \mathrm{kg}^{-1}$ (half the $\mathrm{LD}_{50}$ dose) or $6 \mathrm{mg} \mathrm{kg}^{-1}$ (full $\mathrm{LD}_{50}$ dose) each. We observed the chicks for the signs of cholinergic toxicosis and death within two hours after OP treatment.

\section{Effects of OP insecticides on plasma and brain ChE activities}

Two hours after each OP treatment, the chicks were euthanised to determine plasma and whole brain
ChE activity. The brains of chicks which died within the two hours from poisoning were also included in $\mathrm{ChE}$ determination. However, we did not take blood samples of the dead chicks because of clotting problems. All brain and plasma samples were kept at $-20{ }^{\circ} \mathrm{C}$ pending $\mathrm{ChE}$ analysis within one week. The whole brain was homogenised with a glass homogeniser in an ice bath in a $\mathrm{pH} 8.1$ phosphate barbital buffer at $3 \mathrm{~mL}$ per 100 mg wet weight $(19,31,32)$. An electrometric method described before in chickens $(18,19)$ and other birds $(31,32)$ was used to determine ChE activity in the plasma and brain samples. The reaction mixture contained $3 \mathrm{~mL}$ of distilled water, $0.2 \mathrm{~mL}$ of plasma or brain homogenate, and $3 \mathrm{~mL}$ of $\mathrm{pH} 8.1$ solution of barbital-phosphate buffer $(31,32)$. The $\mathrm{pH}$ of the mixture $(\mathrm{pH} 1)$ was measured using a $\mathrm{pH}$ meter with a glass electrode (Hanna Instruments, Romania). Then $0.10 \mathrm{~mL}$ of the substrate $7.5 \%$ acetylthiocholine iodide (Merck, Germany) was added to the mixture, which was incubated at $37^{\circ} \mathrm{C}$ for $30 \mathrm{~min}$. At the end of the incubation period, the $\mathrm{pH}$ of the reaction mixture (pH2) was measured. Enzyme activity was calculated as follows:

ChE activity in units of $\Delta \mathrm{pH}=(\mathrm{pH} 1-\mathrm{pH} 2)-\Delta \mathrm{pH}$ of the blank

The blank contained no plasma or brain. The barbital-phosphate buffer solution consisted of 1.24 $\mathrm{g}$ sodium barbital (BDH, U.K.), $0.63 \mathrm{~g}$ potassium

Table 2 Inhibition of plasma and whole brain cholinesterase activities in chicks dosed orally with organophosphate insecticides

\begin{tabular}{lcccc}
\hline \multirow{2}{*}{ Organophosphate treatment } & \multicolumn{2}{c}{ Plasma } & \multicolumn{2}{c}{ Whole brain } \\
& $\Delta \mathrm{pH}$ & inhibition $\%$ & $\Delta \mathrm{pH}$ & inhibition \% \\
\hline Control (without treatment) & $0.49 \pm 0.029$ & & & \\
& & & & \\
Chlorpyrifos / $\mathrm{mg} \mathrm{kg}^{-1}$ & & & & \\
$\quad 5$ & $0.35 \pm 0.017$ & 29 & $0.15 \pm 0.036$ & 32 \\
11 & $0.12 \pm 0.054^{*}$ & 76 & $0.05 \pm 0.012^{*}$ & 77 \\
& & & & \\
Diazinon / $\mathrm{mg} \mathrm{kg}^{-1}$ & & & & \\
$\quad 3$ & $0.31 \pm 0.024^{*}$ & 37 & $0.18 \pm 0.017$ & 18 \\
6 & $0.21 \pm 0.031^{*}$ & 57 & $0.10 \pm 0.014^{*}$ & 55 \\
& & & & \\
Dichlorvos / $\mathrm{mg} \mathrm{kg}^{-1}$ & & & & \\
$\quad 3$ & & 49 & $0.09 \pm 0.021^{*}$ & 59 \\
6 & $0.25 \pm 0.027^{*}$ & 84 & $0.05 \pm 0.013^{*}$ & 77 \\
\hline
\end{tabular}

Cholinesterase activity values are expressed as mean \pm SE; $n=18$ chicks in the control group (pooled) and 6 chicks in each organophosphate treatment group. Cholinesterase activity was determined two hours after the insecticide dosing. The number of dead chicks treated with the higher dose of chlorpyrifos, diazinon, and dichlorvos were 2, 2, and 3, respectively, and their plasma cholinesterases were not determined.

* Significantly different from the control value, $p<0.05$ 
dihydrogen phosphate (Merck), and $35.07 \mathrm{~g}$ sodium chloride (BDH) dissolved in one litre of distilled water $(31,32)$.

The percentage of $\mathrm{ChE}$ inhibition was calculated as follows:

\% $\mathrm{ChE}$ inhibition $=[\mathrm{ChE}$ activity (without OP)-ChE activity (with OP)/ ChE activity (without OP)] x 100

$\mathrm{ChE}$ activity values from the three control groups were pooled so that the final number of chicks in the control group was 18. Data as multiple means were subjected to the analysis of variance followed by Tukey's test (33). The level of statistical significance was set at $p<0.05$. The calculation of correlation coefficient (r) between the percentages of brain and plasma ChE inhibitions (using 29 inhibition values of plasma and corresponding brain ChEs of OP-treated chicks) was based on the regression line for both variables (33).

\section{RESULTS}

The acute $\left(24 \mathrm{~h}\right.$ ) oral $\mathrm{LD}_{50}$ of chlorpyrifos, diazinon and dichlorvos in chicks, determined by the up-anddown method, was $10.79 \mathrm{mg} \mathrm{kg}^{-1}, 6.32 \mathrm{mg} \mathrm{kg}^{-1}$, and $6.30 \mathrm{mg} \mathrm{kg}^{-1}$, respectively (Table 1). The signs of cholinergic toxicosis appeared within two hours after dosing and they included salivation, lacrimation, gasping, frequent defecation, drooping of wings, tremors, convulsions, and recumbency before death.

Oral treatment of chicks with half the $\mathrm{LD}_{50}$ dose of chlorpyrifos ( $\left.5 \mathrm{mg} \mathrm{kg}^{-1}\right)$, diazinon $\left(3 \mathrm{mg} \mathrm{kg}^{-1}\right)$, and dichlorvos $\left(3 \mathrm{mg} \mathrm{kg}^{-1}\right)$ caused immobility and wing drooping, but not the clinical signs of cholinergic toxicity seen in the $\mathrm{LD}_{50}$ experiment with these insecticides. However, at full $\mathrm{LD}_{50}$ doses, these $\mathrm{OP}$ insecticides caused clinical signs similar to those seen in the $\mathrm{LD}_{50}$ experiment. Two out of six chicks died within two hours after treatment with either chlorpyrifos and dichlorvos, whereas full $\mathrm{LD}_{50}$ dose of diazinon caused death in three out of 6 chicks. Compared to control animals, the OP insecticides reduced plasma and whole brain $\mathrm{ChE}$ activities by ( 29 to 84 ) $\%$ and (18 to 77 ) \%, respectively, depending on the dose applied (Table 2). Correlation analysis showed that the inhibition of brain $\mathrm{ChE}$ activity correlated well $(r=0.82)$ with that of the plasma ChE activity (Figure 1).

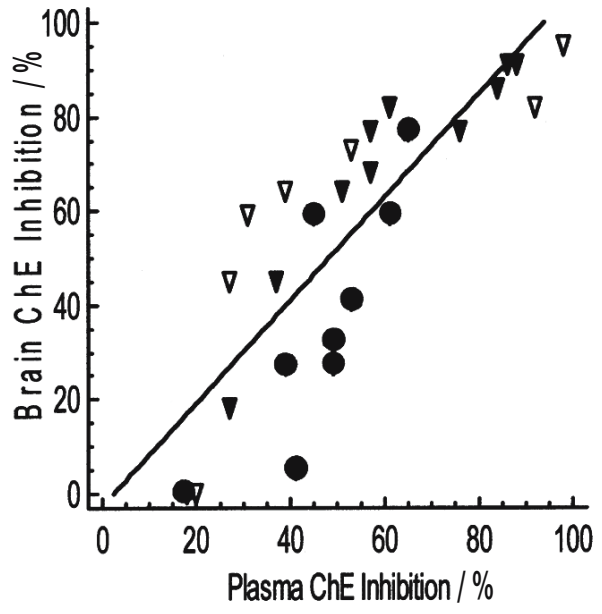

Figure 1 Correlation between inhibition (\%) of brain and plasma cholinesterase (ChE) activities in organophosphate-treated chicks $(n=29) ; r=0.82$. Open triangles $=$ chlorpyrifos, closed circles $=$ diazinon and closed triangles $=$ dichlorvos. See Table 1 for details of treatment and ChE inhibition.

\section{DISCUSSION}

Our findings of the acute toxicity $\left(\mathrm{LD}_{50}\right)$ of chlorpyrifos, dichlorvos, and diazinon in chicks are generally in agreement with their toxic effects reported by others $(20,24,25,34,35)$. In male leghorn chicks the reported acute oral $\mathrm{LD}_{50}$ of chlorpyrifos was $32 \mathrm{mg} \mathrm{kg}^{-1}$ [range: (14 to 72 ) $\mathrm{mg} \mathrm{kg}^{-1}$ ] (34); whereas that of dichlorvos was $6.45 \mathrm{mg} \mathrm{kg}^{-1}$ [range (5.10 to 8.06 ) $\mathrm{mg} \mathrm{kg}^{-1}$ ] (35). The $\mathrm{LD}_{50}$ of diazinon in birds generally ranges between $2.75 \mathrm{mg} \mathrm{kg}^{-1}$ and $40.8 \mathrm{mg} \mathrm{kg}^{-1}$ (36). According to their oral 24-hour $\mathrm{LD}_{50}$, these insecticides could be categorised as highly toxic in chicks $(37,38)$. This supports the classification of OP insecticides according to their toxic potentials $(3,25)$. Several studies have indicated that bird sensitivity to acute OP poisoning does not differ substantially from that of mammals $(12,24,25)$.

In our study, OP insecticides induced in chicks the signs of poisoning characteristic of cholinergic overstimulation. They were in similar to those reported in chickens and other birds acutely poisoned with OP insecticides $(9,19,22,24)$. The main mechanism of toxic action of OP insecticides in the avian species, as well as in mammals, is $\mathrm{ChE}$ inhibition with subsequent development of nicotinic, muscarinic, and central nervous effects $(3,6,24,25)$. Dichlorvos directly inhibits the target $\mathrm{ChE}$, whereas chlorpyrifos and diazinon act through their active oxon metabolites (24-26, 37, 39). 
Reduced ChE activity is still a reliable indicator of OP poisoning and a biomarker of absorption of OP insecticides (3, 4, 6-10). In the avian species, $\mathrm{ChE}$ activities in the brain and plasma are frequently measured to assess the condition of exposure or poisoning $(9,10,12-14,18,19,22,24)$. In this study, the decreases in ChE activity in plasma (29\% to $84 \%$ ) and brain (18\% to $77 \%$ ) were dose-dependent; full $\mathrm{LD}_{50}$ doses of the OP insecticides caused greater enzyme inhibition in plasma ( $57 \%$ to $84 \%$ ) and brain (55\% to $77 \%$ ).

Inhibition of brain $\mathrm{ChE}$ correlated well $(\mathrm{r}=0.82)$ with that of plasma $\mathrm{ChE}$ (Figure 1). Several studies also reported a concurrent drop in plasma and brain ChE activities in chickens acutely poisoned with various dosing regimens of chlorpyrifos $(19,20)$, dichlorvos (23), and diazinon (40). One hour after acute oral administration in chickens, dichlorvos $\left(7 \mathrm{mg} \mathrm{kg}^{-1}\right)$ was reported to cause concurrent decreases in brain and plasma ChE activities by $62 \%$ and $29 \%$, respectively (19). Chlorpyrifos also reduced both brain (43\% to $69 \%$ ) and plasma (40\% to $70 \%$ ) ChE activities in chicks two hours after acute oral administration at doses of $5 \mathrm{mg} \mathrm{kg}^{-1}, 10 \mathrm{mg} \mathrm{kg}^{-1}$, and $20 \mathrm{mg} \mathrm{kg}^{-1}$ (20). Thirty minutes after dosing, diazinon at $10 \mathrm{mg} \mathrm{kg}^{-1}$ orally decreased brain and plasma $\mathrm{ChE}$ in chicks by $20 \%$ and $79 \%$, respectively (40). A similar trend has been observed with brain and blood $\mathrm{ChE}$ activities following OP poisoning in rats $(41,42)$ and wild birds $(9,10)$. However, there are a number of exceptions to this generalisation $(3,6,25,43)$. Many factors may influence the extent of $\mathrm{ChE}$ inhibition in OP poisoning. These include the type of OP, its dose, route and duration of exposure, species involved, toxicokinetic aspects of the insecticide, tissues examined, or sampling time $(3-6,25,33)$.

\section{CONCLUSION}

In conclusion, acute exposure of chicks to OP insecticides is associated with concurrent reductions in brain and plasma ChE activities and with signs of poisoning at doses close to their $\mathrm{LD}_{50}$ in the surviving birds. Further studies are needed to (re)evaluate the toxicity and $\mathrm{ChE}$ inhibition of other OP insecticides using chicks as a suitable animal model for acute OP toxicity studies.

\section{Acknowledgement}

This study was supported by the College of Veterinary Medicine, University of Mosul, Mosul, Iraq.

\section{REFERENCES}

1. Coggon D. Work with pesticides and organophosphate sheep dips. Occup Med 2002;52:467-70.

2. Jaga K, Dhamani C. Sources of exposure to and public health implications of organophosphate pesticides. Rev Panam Salud Púb 2003;14:171-85.

3. Wilson BW. Cholinesterase inhibition. In: Wexler P, editor. Encyclopedia of toxicology. Vol. 1. San Diego (CA): Academic Press; 1998. p. 326-40.

4. Kwong TC. Organophosphate pesticides: biochemistry and clinical toxicology. Therap Drug Monit 2002;24:1449.

5. Rusyniak DE, Nanagas KA. Organophosphate poisoning. Semin Neurol 2004;24:197-204.

6. Wilson BW. Clinical enzymology. In: Loeb WF, Quimby FW, editors. The clinical chemistry of laboratory animals. Philadelphia (PA): Taylor and Francis; 1999. p. 399-454.

7. Cocker J, Mason HJ, Garfitt SJ, Jones K. Biological monitoring of exposure to organophosphate pesticides. Toxicol Lett 2002;134:97-103.

8. Wilson BW, Arrieta DE, Henderson JD. Monitoring cholinesterases to detect pesticides exposure. Chem Biol Interact 2005;157-158:253-6.

9. Cairns MA, Maguire CC, Williams BA. Brain cholinesterase activity of bobwhite acutely exposed to chlorpyrifos. Environ Toxicol Chem 1991;10:657-64.

10. Parsons KC, Matz AC, Hooper MJ, Pokras MA. Monitoring wading birds exposure to agricultural chemicals using serum cholinesterase activity. Environ Toxicol Chem 2000;19:1317-23.

11. Roy C, Grolleau G, Chamoulaud S, Riviere J. Plasma B-esterase activities in European raptors. J Wildl Dis 2005;41:184-208.

12. Fossi MC, Leonzio C, Massi A, Lari L, Casini S. Serum esterase inhibition in birds: a nondestructive biomarker to assess organophosphorus and carbamate contamination. Arch Environ Contam Toxicol 1992;23:99-104.

13. Mclnnes PF, Anderson DE, Hoff DJ, Hooper, MJ, Kinkel LL. Monitoring exposure of nestling songbirds to agricultural application of an organophosphorus insecticide using cholinesterase activity. Environ Toxicol Chem 1996;15:544-52.

14. Iko WM, Archuleta AS, Knop FL. Plasma cholinesterase levels of mountain plovers (Charadrius Montanus) wintering in central California, USA. Environ Toxicol Chem 2003;22:119-25.

15. Wilson BW, Henderson JD. Blood esterase determinations as markers of exposure. Rev Environ Contam Toxicol 1992;128:55-69.

16. Burn JD, Leighton FA. Further studies of brain cholinesterase: Cholinergic receptor ratios in the diagnosis of acute lethal poisoning of birds by anticholinesterase pesticides. J Wildl Dis 1996;32:21624. 
17. Farage-Elawar M, Francis MB. Effect of multiple dosing of fenthion, fenitrothion and desbromoleptophos in young chicks. J Toxicol Environ Health 1988;23:21728.

18. Abass KS, Mohammad FK. Validation of an electrometric method for cholinesterase measurement in the plasma and tissues of the chicken. In: Proceedings of the $11^{\text {th }}$ Scientific Congress Faculty of Veterinary Medicine, Assiut University; 5-7 Dec 2004; Assiut, Egypt. Assuit: Faculty of Veterinary Medicine, Assiut University; 2004. p. 241-59.

19. Mohammad FK, Al-Baggou B. Electrometric cholinesterase determination in poultry treated with dichlorvos and carbaryl. Online J Vet Res 2005;9:15.

20. Al-Badrany YMA, Mohammad FK. Effects of acute and repeated oral exposure to the organophosphate insecticide chlorpyrifos on open-field activity in chicks. Toxicol Lett 2007;174:110-6.

21. Malik G, Agarwal VK, Gera S, Dahiya JP. Studies on growth pattern and feed efficiency in broiler chickens following chlorpyrifos intoxication. Haryana Vet 2001;40:38-40.

22. Vodela JK, Dalvi RR. Comparative toxicological studies of chlorpyrifos in rats and chickens. Vet Hum Toxicol 1995;37:1-3.

23. Abdelsalam EB. Neurotoxic potential of six organophosphorus compounds in adult hens. Vet Hum Toxicol 1999;41:290-2.

24. Clegg DJ, van Gemert M. Determination of the reference dose for chlorpyrifos: proceedings of an expert panel. J Toxicol Environ Health Part B 1999;2:211-55.

25. World Health Organization (WHO). Organophosphorus insecticides: a general introduction. Environmental Health Criteria, No. 63. Geneva: World Health Organization; 1986.

26. Richardson RJ, Moore TB, Kayyali US, Fowke JH, Randall JC. Inhibition of hen brain acetylcholinesterase and neurotoxic esterase by chlorpyrifos in vivo and kinetics of inhibition by chlorpyrifos oxon in vitro: application to assessment of neuropathic risk. Fundam Appl Toxicol 1993;20:273-9.

27. Richardson JR, Chambers HW, Chambers JE. Analysis of the additivity of in vitro inhibition of cholinesterase by mixtures of chlorpyrifos-oxon and azinphos-methyloxon. Toxicol Appl Pharmacol 2001;172:128-39.

28. Wilson BW, Henderson JD, Kellner TP, Goldman M, Higgins RJ, Dacre JC. Toxicity of repeated doses of organophosphorus esters in the chicken. $\mathrm{J}$ Toxicol Environ Health 1988;23:115-26.
29. Abou-Donia MB, Wilmarth KR, Abdel-Rahman AA, Jensen KF, Oehme FW, Kurt TL. Increased neurotoxicity following concurrent exposure to pyridostigmine bromide, DEET and chlrpyrifos. Fundam Appl Toxicol 1996;34:201-22.

30. Dixon WJ. Efficient analysis of experimental observations. Ann Rev Pharmacol Toxicol 1980;20:44162.

31. Alias AS, Mohammad FK. Electrometric measurement of plasma and tissue cholinesterase activities of four wild birds in Iraq. J Biol Res 2005;4:197-202.

32. Mohammad FK. Review of a practical electrometric method for determination of blood and tissue cholinesterase activities in animals. Vet Scan 2007;2:112.

33. Petrie A, Watson P. Statistics for veterinary and animal science. Oxford: Blackwell Science Ltd; 1999.

34. McCollister SB, Kociba RJ, Humiston CG, McCollister DD, Gehring PJ. Studies on the acute and long-term oral toxicity of chlorpyrifos $(0,0$-diethyl-O(3,5,6trichloro-2-pyidyl) phosphorothioate). Food Cosmet Toxicol 1974;12:46-61.

35. Naidu NV, Reddy KS, Janadhan A, Murthy MK. Toxicological investigation of dichlorvos in chicks. Indian J Pharmacol 1978;10:323-6.

36. World Health Organization (WHO). Diazinon. Environmental Health Criteria, No. 198. Geneva: World Health Organization; 1998.

37. Osweiler GD, Carson TL, Buck WB, Van-Gelder GA. Clinical and diagnostic veterinary toxicology. $3^{\text {rd }}$ ed. Dubuque, IA, USA: Kendall Publishing Co.; 1985.

38. Osweiler GD. Toxicology. Philadelphia (PA): Williams and Wilkins; 1996.

39. Costa LG. Current issues in organophosphate toxicology. Clin Chim Acta 2006;366:1-13.

40. Al-Zubaidy MIH, Mohammad FK. Metoclopramide protection of diazinon-induced toxicosis in chickens. J Vet Sci 2007;8:249-54.

41. Padilla S, Wilson VZ, Bushnell PJ. Studies on the correlation between blood cholinesterase inhibition and target tissue inhibition in pesticide treated rats. Toxicology 1994;92:11-25.

42. Guilhermino L, Soares AMVM, Carvalho AP, Lopes MC. Correlation between whole blood cholinesterase activity and cerebral cortex cholinesterase activity in rats treated with parathion. Chemosphere 1998;37:1385-93.

43. Yawetz A, Zook-Rimon Z, Dotan A. Cholinesterase profiles in two species of wild birds exposed to insecticide sprays in their natural habitat. Arch Insect Biochem Physiol 1993;22:501-9. 


\section{Sažetak}

\section{AKUTNA ORALNA TOKSIČNOST ORGANOFOSFORNIH INSEKTICIDA I INHIBICIJA KOLINESTERAZA U PILIĆA}

Ispitano je akutno toksično djelovanje triju često rabljenih organofosfornih insekticida klorpirifosa, diazinona i diklorvosa u brojlera te je izmjerena aktivnost kolinesteraza u njihovoj plazmi i mozgu. Srednja letalna doza $\mathrm{LD}_{50}$ klorpirifosa iznosila je $10,79 \mathrm{mg} \mathrm{kg}^{-1}$, diazinona $6,32 \mathrm{mg} \mathrm{kg}^{-1}$ te diklorvosa $6,30 \mathrm{mg} \mathrm{kg}^{-1}$. Prvi su se znakovi kolinergičkoga sindroma u pilića javili unutar dva sata od oralne primjene, a obuhvaćali su slinjenje, suženje, teško disanje, učestalu defekaciju, obješena krila, drhtavicu, grčenje i nesposobnost stajanja uoči smrti. Oralna primjena polovice srednje letalne doze insekticida klorpirifosa $\left(5 \mathrm{mg} \mathrm{kg}^{-1}\right)$, diazinona $\left(3 \mathrm{mg} \mathrm{kg}^{-1}\right)$ i diklorvosa $\left(3 \mathrm{mg} \mathrm{kg}^{-1}\right)$ dovela je do nepokretnosti i obješenih krila, ali bez kliničkih znakova kolinergičke toksičnosti koji su uočeni kod pokusa radi utvrđivanja srednje letalne doze (LD50). Međutim, doze ovih insekticida koje su odgovarale $\mathrm{LD}_{50}$, dovele su do kliničkih znakova kolinergičke toksičnosti sličnih onima zamijećenim kod utvrđivanja $\mathrm{LD}_{50}$. Dva od šest pilića uginula su unutar dva sata od primjene bilo klorpirifosa bilo diklorvosa u dozama koje su odgovarale $\mathrm{LD}_{50}$, dok je diazinon $\mathrm{u}$ odgovarajućoj srednjoj letalnoj dozi uzrokovao smrt triju od šest pilića. U odnosu na kontrolne vrijednosti, insekticidi su doveli do smanjenja aktivnosti kolinesteraze koja je ovisila o dozi, a kretala se od $29 \%$ do $84 \%$ u plazmi te od $18 \%$ do $77 \%$ u mozgu. Pad aktivnosti kolinesteraze u plazmi dobro je korelirao s njezinim padom u mozgu $(\mathrm{r}=0,82)$. Ovi podaci upućuju na to da oralna primjena organofosfornih insekticida u dozama koje odgovaraju srednjoj letalnoj dozi dovode do znakova kolinergičkoga trovanja u pilića te do istodobnoga pada aktivnosti kolinesteraza u mozgu i plazmi.

KLJUČNE RIJEČI: antikolinesteraze, diazinon, diklorvos, klorpirifos, kolinergička toksičnost, $L D_{50}$

\section{CORRESPONDING AUTHOR:}

\section{Fouad K. Mohammad}

Department of Physiology, Biochemistry

and Pharmacology, College of Veterinary Medicine

University of Mosul, Mosul, Iraq

E-mail: fouadmohammad@yahoo.com 